\title{
Kinetics and Mechanism of the Chlorine Dioxide-Tetrathionate Reaction
}

\author{
Attila K. Horváth, ${ }^{\dagger}$ István Nagypál, ${ }^{*, \dagger}$ and Irving R. Epstein $*, *$ \\ Department of Physical Chemistry, University of Szeged, Szeged, P.O. Box 105, H-6701 Hungary, and \\ Department of Chemistry, Brandeis University, MS 015, Waltham, Massachusetts 02454-9110
}

Received: April 2, 2003; In Final Form: September 8, 2003

\begin{abstract}
The chlorine-dioxide-tetrathionate reaction was studied spectrophotometrically in the $\mathrm{pH}$ range $4.55-5.55$ at $25.0 \pm 0.2{ }^{\circ} \mathrm{C}$ and $0.5 \mathrm{M}$ ionic strength adjusted with sodium acetate as a buffer component. The stoichiometry was found to be $\mathrm{S}_{4} \mathrm{O}_{6}{ }^{2-}+4^{\circ} \mathrm{ClO}_{2}+5 \mathrm{H}_{2} \mathrm{O} \rightarrow 4 \mathrm{SO}_{4}{ }^{2-}+\mathrm{ClO}_{3}{ }^{-}+3 \mathrm{Cl}^{-}+10 \mathrm{H}^{+}$with small deviations at high excess of chlorine dioxide with no chloride ion initially present. The initial presence of chloride not only affects the stoichiometry but also accelerates the reaction. A 14-step mechanism, including four known and two newly proposed intermediates, is suggested to describe the observed behavior of the system.
\end{abstract}

\section{Introduction}

A remarkable variety of "exotic" phenomena such as complex periodic and aperiodic oscillations in a flow reactor, ${ }^{1}$ autocatalysis $^{2}$ and stochastic reaction time distributions under batch conditions, ${ }^{3}$ and propagation of reaction fronts in unstirred mixtures ${ }^{4}$ have been observed in the chlorite-thiosulfate reaction. The ultimate goal of investigations of this system is to understand and describe quantitatively these and related phenomena. Accomplishing this task is, however, impossible without insight into the mechanism of the reaction. As part of the attempt to elucidate the mechanism of the fascinating chlorite-thiosulfate reaction, several subsystems of the parent reaction have been investigated. The kinetics and mechanisms of the chlorite-hypochlorous acid, ${ }^{5}$ thiosulfate-chlorine dioxide ${ }^{6}$ tetrathionate-hypochlorous acid, ${ }^{7}$ and chlorine dioxidehypochlorite ${ }^{8}$ reactions have been established. It has also been shown ${ }^{4}$ that at least two long-lived intermediates, chlorine dioxide and the tetrathionate ion, formed in the chloritethiosulfate reaction can be end products as well, depending upon the initial concentration ratio of the reactants. These versatile intermediates can also react with the reactants or with each other. As a part of the ongoing systematic kinetics studies of the subsystems of the chlorite-thiosulfate reaction, we report here the first detailed investigations of the reaction between chlorine dioxide and tetrathionate ion.

\section{Experimental Section}

Materials. Chlorine dioxide stock solution was prepared by oxidizing $\mathrm{NaClO}_{2}$ solution in $10 \% \mathrm{H}_{2} \mathrm{SO}_{4}$ with $\mathrm{K}_{2} \mathrm{~S}_{2} \mathrm{O}_{8}$. The $\cdot \mathrm{ClO}_{2}$ evolved was removed with an air stream and dissolved in cold water. The stock solution was kept refrigerated and was protected from light. It was checked daily for $\mathrm{Cl}^{-}, \mathrm{H}^{+}, \mathrm{ClO}_{2}{ }^{-}$, and $\mathrm{ClO}_{3}{ }^{-}$. None of these impurities were detectable for up to one month. All other chemicals were of the highest quality commercially available. All solutions were prepared with Milli-Q water of $18.2 \mu \mathrm{S} \mathrm{cm}^{-1}$ conductivity. The ionic strength was adjusted to $0.5 \mathrm{M}$ in all measurements with sodium acetate

* To whom correspondence should be addressed.

$\dagger$ University of Szeged.

$\doteqdot$ Brandeis University.
TABLE 1: Initial Concentrations of Reactants

\begin{tabular}{|c|c|c|c|c|}
\hline run no. & $\begin{array}{c}{\left[{ }^{\circ} \mathrm{ClO}_{2}\right]} \\
(\mathrm{mM})\end{array}$ & $\begin{array}{c}{\left[\mathrm{S}_{4} \mathrm{O}_{6}{ }^{2-}\right]} \\
(\mathrm{mM})\end{array}$ & $\mathrm{pH}$ & $\begin{array}{l}{\left[\mathrm{Cl}^{-}\right]} \\
(\mathrm{mM})\end{array}$ \\
\hline $1-6$ & 4 & $0.4,0.6,1,2,3,4$ & 4.55 & 0 \\
\hline $3,7-11$ & $0.8,1.2,2,4,6,8$ & 1 & 4.55 & 0 \\
\hline 12 & 0.8 & 4 & 4.55 & 0 \\
\hline 13 & 1.2 & 3 & 4.55 & 0 \\
\hline $14-16$ & 2 & 2 & 4.55 & $0,3,10$ \\
\hline $17-19$ & 6 & 0.6 & 4.55 & $0,3,10$ \\
\hline 20 & 8 & 0.4 & 4.55 & 0 \\
\hline $3,21,22$ & 4 & 1 & 4.55 & $0,3,10$ \\
\hline $23-28$ & 4 & $0.4,0.6,1,2,3,4$ & 4.85 & 0 \\
\hline $25,29-33$ & $0.8,1.2,2,4,6,8$ & 1 & 4.85 & 0 \\
\hline 34 & 0.8 & 4 & 4.85 & 0 \\
\hline 35 & 1.2 & 3 & 4.85 & 0 \\
\hline $36-38$ & 2 & 2 & 4.85 & $0,3,10$ \\
\hline $39-41$ & 6 & 0.6 & 4.85 & $0,3,10$ \\
\hline 42 & 8 & 0.4 & 4.85 & 0 \\
\hline $25,43,44$ & 4 & 1 & 4.85 & $0,3,10$ \\
\hline $45-50$ & 4 & $0.4,0.6,1,2,3,4$ & 5.25 & 0 \\
\hline $47,51-55$ & $0.8,1.2,2,4,6,8$ & 1 & 5.25 & 0 \\
\hline 56 & 0.8 & 4 & 5.25 & 0 \\
\hline 57 & 1.2 & 3 & 5.25 & 0 \\
\hline $58-60$ & 2 & 2 & 5.25 & $0,3,10$ \\
\hline $61-63$ & 6 & 0.6 & 5.25 & $0,3,10$ \\
\hline 64 & 8 & 0.4 & 5.25 & 0 \\
\hline $47,65,66$ & 4 & 1 & 5.25 & $0,3,10$ \\
\hline $67-72$ & 4 & $0.4,0.6,1,2,3,4$ & 5.55 & 0 \\
\hline $69,73-77$ & $0.8,1.2,2,4,6,8$ & 1 & 5.55 & 0 \\
\hline 78 & 0.8 & 4 & 5.55 & 0 \\
\hline 79 & 1.2 & 3 & 5.55 & 0 \\
\hline $80-82$ & 2 & 2 & 5.55 & $0,3,10$ \\
\hline $83-85$ & 6 & 0.6 & 5.55 & $0,3,10$ \\
\hline 86 & 8 & 0.4 & 5.55 & 0 \\
\hline $69,87,88$ & 4 & 1 & 5.55 & $0,3,10$ \\
\hline
\end{tabular}

as a buffer component. The $\mathrm{pH}$ of the solutions was regulated between 4.55 and 5.55 by adding the appropriate amount of acetic acid. Table 1 summarizes the $\mathrm{pH}$ and concentration range of the reactants and chloride ion used in the kinetic experiments. The concentration ratio of the reactants, $\left[{ }^{\circ} \mathrm{ClO}_{2}\right] /\left[\mathrm{S}_{4} \mathrm{O}_{6}{ }^{2-}\right]$, was varied between 0.2 and 20 in order to gain as much information about the reaction as possible.

Methods. The stoichiometry of the reaction was studied by simple iodometry in excess chlorine dioxide and by gravimetry in excess tetrathionate to determine the amount of sulfate, as barium sulfate, formed in the reaction. These tests were 
TABLE 2: Results of Stoichiometric Studies in Excess Tetrathionate (Upper Half of Table) and in Excess Chlorine Dioxide (Lower Half of Table) ${ }^{a}$

\begin{tabular}{rrllclc}
\hline$\left[\mathrm{S}_{4} \mathrm{O}_{6}{ }^{2-}\right]_{0}$ & {$\left[{ }^{\circ} \mathrm{ClO}_{2}\right]_{0}$} & {$\left[\mathrm{Cl}^{-}\right]_{0}$} & $\mathrm{pH}$ & $\mathrm{BaSO}_{4}(\mathrm{~g})$ & {$\left[{ }^{\circ} \mathrm{ClO}_{2}\right]_{\infty}$} & $\mathrm{SR}$ \\
\hline 5.0 & 4.89 & 0 & 4.55 & 0.0568 & 0 & 4.018 \\
8.0 & 15.73 & 0 & 4.85 & 0.1807 & 0 & 4.063 \\
8.0 & 15.22 & 0 & 4.85 & 0.1793 & 0 & 3.983 \\
10.0 & 7.92 & 0 & 4.55 & 0.0928 & 0 & 3.962 \\
10.0 & 11.27 & 0 & 4.85 & 0.1302 & 0 & 4.040 \\
10.0 & 11.02 & 0 & 4.55 & 0.1035 & 0 & 3.941 \\
12.0 & 22.37 & 0 & 4.55 & 0.2576 & 0 & 4.053 \\
12.0 & 22.10 & 0 & 4.85 & 0.2531 & 0 & 4.075 \\
12.0 & 21.98 & 0 & 4.85 & 0.2603 & 0 & 3.940 \\
1.0 & 8.37 & 0 & 4.55 & & 4.16 & 4.210 \\
1.0 & 6.72 & 0 & 4.55 & & 2.57 & 4.150 \\
2.0 & 14.33 & 0 & 4.85 & & 5.99 & 4.170 \\
2.0 & 13.78 & 0 & 4.85 & & 5.57 & 4.105 \\
5.0 & 29.68 & 0 & 4.55 & & 9.03 & 4.130 \\
5.0 & 29.11 & 0.01 & 4.55 & & 9.06 & 4.010 \\
5.0 & 29.01 & 0.01 & 4.25 & & 8.97 & 4.008 \\
5.0 & 28.88 & 0.01 & 4.85 & & 8.94 & 3.988 \\
5.0 & 28.76 & 0.01 & 4.85 & & 8.83 & 3.986
\end{tabular}

${ }^{a}$ Stoichiometric ratio $\mathrm{SR}=\left[{ }^{\circ} \mathrm{ClO}_{2}\right] /\left[\mathrm{S}_{4} \mathrm{O}_{6}{ }^{2-}\right]$ consumed in the reaction. All concentrations are in $\mathrm{mM}$.

performed after the reaction was complete. Carefully sealed 50 $\mathrm{mL}$ reaction vessels were used to mix the appropriate amounts of the reactants. The kinetics measurements were carried out in a standard $1 \mathrm{~cm}$ quartz cuvette equipped with a Teflon cap and a magnetic stirrer. The cuvette was carefully sealed with Parafilm at the Teflon cap to minimize loss of chlorine dioxide. In separate experiments, the loss of ${ }^{\cdot} \mathrm{ClO}_{2}$ was checked by monitoring its concentration for $4 \mathrm{~h}-$ more than the longest runand no significant loss was detected. The reaction was followed at three wavelengths $(430,435$, and $440 \mathrm{~nm})$ with a Zeiss Specord S10 diode array spectrophotometer, excluding ultraviolet light in order to avoid the photochemical decomposition of tetrathionate ion. ${ }^{9}$

Data Treatment. Only measurements up to 1.2 absorbance units were used in our analysis, because the relative error of absorbance measurements above this value is unacceptably high. Because each kinetic curve contained 250-300 data points, the number of points in each run was reduced to $49-50$ to avoid unnecessary and time-consuming calculations. The point reduction algorithm was based on the principle of equivalent arclength in order to avoid losing any significant chemical information.

The number of absorbing species in this wavelength range was investigated by matrix rank analysis, ${ }^{10}$ and no absorbing species was found other than chlorine dioxide.

The experimental curves were analyzed with the program package $\mathrm{ZiTa},{ }^{12}$ developed for fitting kinetic data. Altogether 10557 experimental points from the 264 absorbance-time series were used for simultaneous fitting. The sum of squares of the deviations between the experimentally measured and calculated absorbances was selected as the parameter to be minimized.

\section{Results}

Stoichiometry. Our stoichiometric studies, summarized in Table 2, convincingly demonstrate that the fundamental stoichiometry of the reaction is

$$
\begin{aligned}
& \mathrm{S}_{4} \mathrm{O}_{6}{ }^{2-}+4^{*} \mathrm{ClO}_{2}+5 \mathrm{H}_{2} \mathrm{O} \rightarrow \\
& \quad 4 \mathrm{SO}_{4}{ }^{2-}+\mathrm{ClO}_{3}{ }^{-}+3 \mathrm{Cl}^{-}+10 \mathrm{H}^{+}
\end{aligned}
$$

Slight deviations from the 1:4 ratio predicted from eq 1 were found in excess chlorine dioxide when no chloride was present

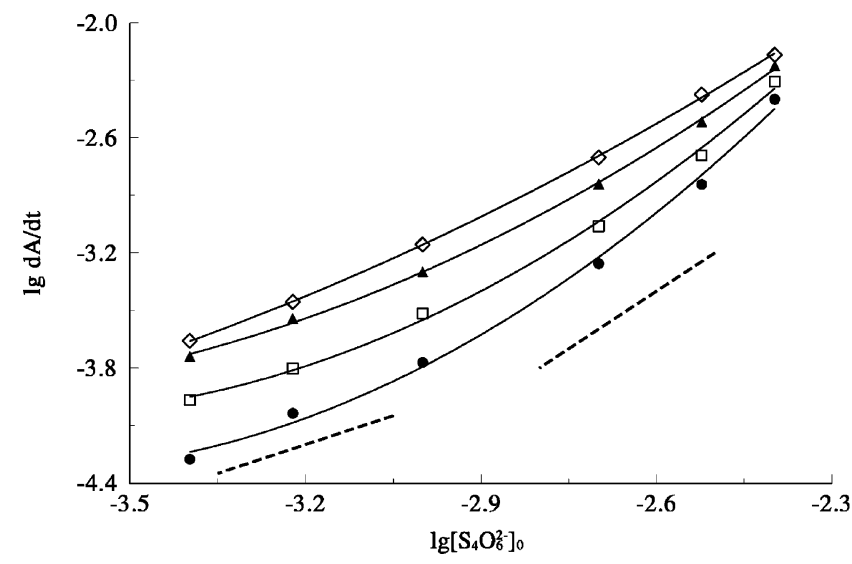

Figure 1. Second-degree polynomial fit of the measured initial rate at $\left[{ }^{\circ} \mathrm{ClO}_{2}\right]_{0}=3.94 \times 10^{-4} \mathrm{M} . \mathrm{pH}=5.55(\bullet), 5.25(\square), 4.85(\mathbf{\Delta})$, and $4.55(\diamond)$. Dashed lines have slopes 1 and 2.

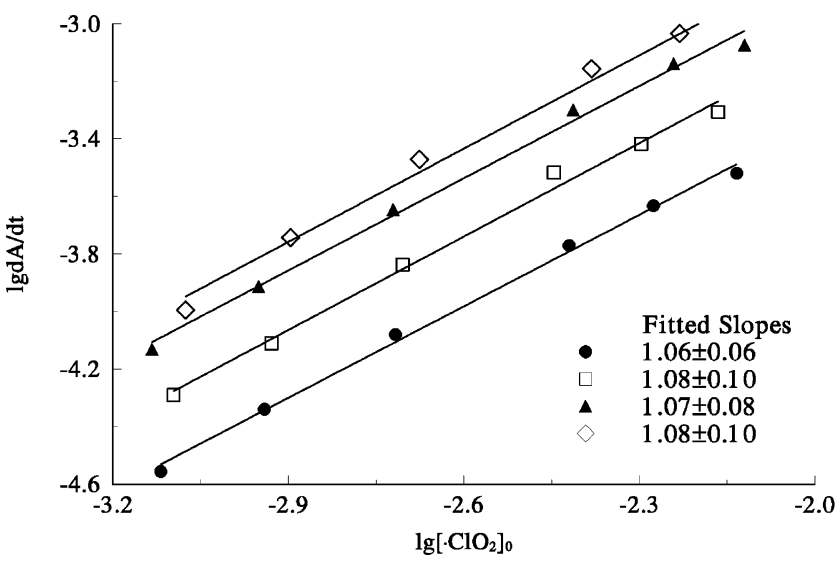

Figure 2. Dependence of initial rate on $\left[{ }^{\circ} \mathrm{ClO}_{2}\right]_{0}$ at $\left[\mathrm{S}_{4} \mathrm{O}_{6}{ }^{2-}\right]_{0}=1.0 \times$ $10^{-4}$ M. pH = $5.55(\bullet), 5.25(\square), 4.85(\mathbf{\bullet})$, and $4.55(\diamond)$.

initially, but with added chloride, the stoichiometric ratio was always 1:4 within experimental error. We propose that the stoichiometric equation that characterizes the deviation from the $1: 4$ stoichiometry is

$$
\begin{aligned}
\mathrm{S}_{4} \mathrm{O}_{6}{ }^{2-}+ & 6{ }^{\circ} \mathrm{ClO}_{2}+6 \mathrm{H}_{2} \mathrm{O} \rightarrow \\
& 4 \mathrm{SO}_{4}{ }^{2-}+2 \mathrm{ClO}_{3}{ }^{-}+2 \mathrm{Cl}^{-}+2 \mathrm{HOCl}+10 \mathrm{H}^{+}
\end{aligned}
$$

This equation may seem unnecessarily complicated, but it is easily understood from our proposed mechanism (see below). It should also be noted that in excess chlorine dioxide hypochlorous acid is an end product, because the hypochlorous acidchlorine dioxide reaction is very slow in the $\mathrm{pH}$ range used in our experiments. The latter reaction becomes significant at higher $\mathrm{pH}$, indicating that hypochlorite ion is the active species in the hypochlorite-chlorine dioxide reaction. ${ }^{8}$

Initial Rate Studies. Because the only absorbing species in the given wavelength range is ${ }^{\circ} \mathrm{ClO}_{2}, \mathrm{~d} A / \mathrm{d} t$ is directly proportional to $\mathrm{d}\left[{ }^{\circ} \mathrm{ClO}_{2}\right] / \mathrm{d} t$. The former values were used to analyze the initial rates. The following conclusions can be drawn based upon these studies.

(i) As seen in Figure 1, the dependence of the initial rate on $\left[\mathrm{S}_{4} \mathrm{O}_{6}{ }^{2-}\right]$ is mixed, first and second order. At low $\mathrm{pH}$, this dependence is nearly first order, but as the $\mathrm{pH}$ increases, the second-order behavior begins to dominate.

(ii) The initial rate is found to be first order in $\left[{ }^{\circ} \mathrm{ClO}_{2}\right]$, as seen in Figure 2. This result is independent of $\mathrm{pH}$.

(iii) At fixed $\left[{ }^{\circ} \mathrm{ClO}_{2}\right]$, the $\mathrm{pH}$ dependence of the initial rate varies with $\left[\mathrm{S}_{4} \mathrm{O}_{6}{ }^{2-}\right]$, becoming stronger as $\left[\mathrm{S}_{4} \mathrm{O}_{6}{ }^{2-}\right]$ decreases, as illustrated in Figure $3 \mathrm{a}$. 

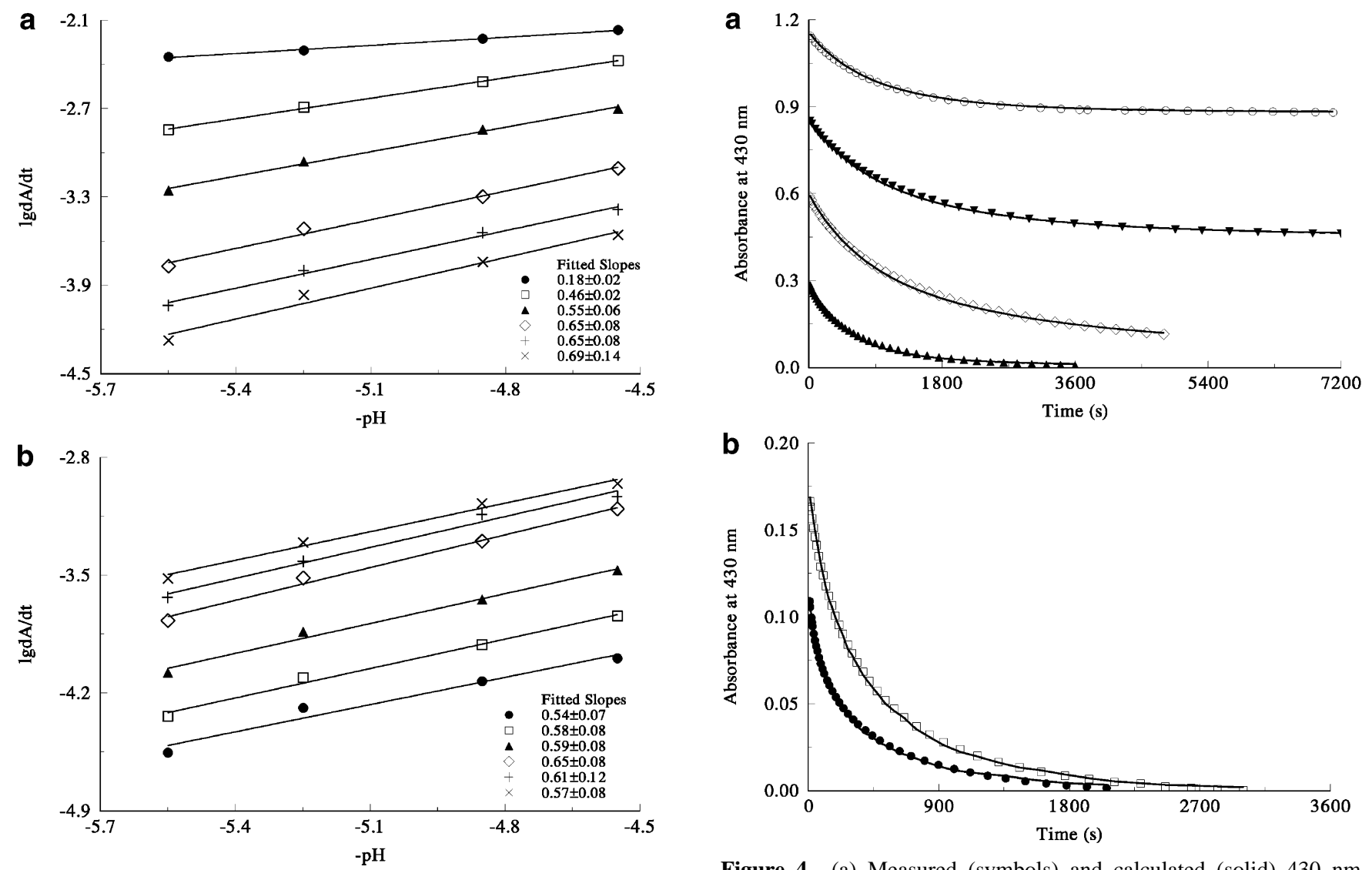

Figure 3. (a) Dependence of initial rate on $\mathrm{pH}$ at $\left[{ }^{\circ} \mathrm{ClO}_{2}\right]_{0}=4.0 \times$ $10^{-3}$ M. $\left[\mathrm{S}_{4} \mathrm{O}_{6}{ }^{2-}\right]_{0}(\mathrm{mM})=4.0(\bullet), 3.0(\square), 2.0(\mathbf{\Delta}), 1.0(\diamond), 0.6(+)$, and $0.4(\times)$. (b) Dependence of initial rate on $\mathrm{pH}$ at $\left[\mathrm{S}_{4} \mathrm{O}_{6}{ }^{2-}\right]_{0}=1.0 \times$ $10^{-3} \mathrm{M} .\left[{ }^{\circ} \mathrm{ClO}_{2}\right]_{0}(\mathrm{mM})=0.8(\bullet), 1.2(\square), 2.0(\mathbf{\bullet}), 4.0(\diamond), 6.0(+)$, and $8.0(\times)$.

(iv) At constant $\left[\mathrm{S}_{4} \mathrm{O}_{6}{ }^{2-}\right]$, in contrast, we find the $\mathrm{pH}$ dependence of the initial rate to be independent of $\left[{ }^{\circ} \mathrm{ClO}_{2}\right]$, as shown in Figure $3 b$. The average slope, $0.59 \pm 0.04$, suggests that there may be $\mathrm{H}^{+}$-dependent and $\mathrm{H}^{+}$-independent steps involved in the initial portion of the reaction.

Important Characteristics of the Kinetic Curves. In addition to the results of the initial rate studies, we note the following additional observations drawn from analysis of the full kinetic curves. In Figures 4-6, solid lines represent the fitted curves obtained from our proposed mechanism.

(i) Figure 4 shows Job-type kinetics experiments, in which $\left[{ }^{\circ} \mathrm{ClO}_{2}\right]$ and $\left[\mathrm{S}_{4} \mathrm{O}_{6}{ }^{2-}\right]$ were varied in opposite directions in order to explore a wide range of initial reactant concentration ratios. The trend of the kinetics curves when $\mathrm{S}_{4} \mathrm{O}_{6}{ }^{2-}$ is in large excess suggests formation of a relatively long-lived intermediate.

(ii) In tetrathionate excess and near the 1:4 stoichiometric ratio, the presence of initial chloride accelerates the reaction, as illustrated in Figure 5.

(iii) In chlorine dioxide excess, added initial chloride not only accelerates the reaction but also shifts the stoichiometry, as shown in Figure 6. At high initial $\left[\mathrm{Cl}^{-}\right]$, the stoichiometric ratio is $1: 4$, but in the absence of chloride, it is somewhat higher, as implied by eq 2 (see also Table 2 ).

Proposed Mechanism. The approach used to generate the proposed model is discussed in detail elsewhere. ${ }^{12}$ The essence of the procedure is to take all of the chemically plausible monoand bimolecular reactions and start the fitting with rate coefficients assigned to the reactions in such a way that the initial mean square deviation between the measured and fitted absorbances is sensitive to each of them. Parameters that become

Figure 4. (a) Measured (symbols) and calculated (solid) $430 \mathrm{~nm}$ absorbances at $\mathrm{pH}=4.85$ in the absence of chloride. $\left[\mathrm{S}_{4} \mathrm{O}_{6}{ }^{2-}\right]_{0}(\mathrm{M})=$ $0.002(\mathbf{\Delta}), 0.001(\diamond), 0.0006(\boldsymbol{\nabla})$, and $0.0004(\mathrm{O})$ and $\left[{ }^{\circ} \mathrm{ClO}_{2}\right]_{0}(\mathrm{M})=$ $0.00190(\mathbf{\Lambda}), 0.00386(\diamond), 0.00558(\boldsymbol{\nabla})$, and $0.00749(\bigcirc)$, respectively. (b) Measured (symbols) and calculated (solid) $430 \mathrm{~nm}$ absorbances at $\mathrm{pH}=4.85$ in the absence of chloride. $\left[\mathrm{S}_{4} \mathrm{O}_{6}{ }^{2-}\right]_{0}(\mathrm{M})=0.004(\bullet)$ and $0.003(\square)$ and $\left[{ }^{\circ} \mathrm{ClO}_{2}\right]_{0}(\mathrm{M})=0.000755(\bullet)$ and $0.00113(\square)$, respectively.

insensitive, meaning that the corresponding process does not affect the fitted curves, are omitted at each step. Finally, only the most sensitive parameters remain in the model. The most critical part of this procedure is to choose the set of species involved in the mono- and bimolecular reactions. Of course, the reactants, the end products, and the solvent must be included. This group consists of $\mathrm{S}_{4} \mathrm{O}_{6}{ }^{2-},{ }^{-} \mathrm{ClO}_{2}, \mathrm{Cl}^{-}, \mathrm{SO}_{4}{ }^{2-}, \mathrm{ClO}_{3}{ }^{-}, \mathrm{HOCl}$, $\mathrm{H}_{2} \mathrm{O}$, and $\mathrm{H}^{+}$. Additional intermediates ${ }^{\circ} \mathrm{S}_{4} \mathrm{O}_{6} \mathrm{ClO}_{2}{ }^{2-}, \cdot\left(\mathrm{S}_{4} \mathrm{O}_{6}\right)_{2-}$ $\mathrm{ClO}_{2}{ }^{4-}, \mathrm{S}_{2} \mathrm{O}_{3} \mathrm{ClO}_{2}{ }^{-}, \mathrm{S}_{2} \mathrm{O}_{3}{ }^{-}, \mathrm{S}_{2} \mathrm{O}_{3}\left(\mathrm{ClO}_{2}\right)_{2}{ }^{-}$, and $\mathrm{S}_{4} \mathrm{O}_{6}\left(\mathrm{ClO}_{2}\right)_{2}{ }^{2-}$ were chosen for the following reasons:

(i) Several studies $6,13,14$ of the reactions of chlorine dioxide have suggested a first step in which a weak adduct is formed. By analogy, we propose ${ }^{\circ} \mathrm{S}_{4} \mathrm{O}_{6} \mathrm{ClO}_{2}{ }^{2-}$.

(ii) To explain the mixed first and second-order dependence of the initial rate (Figure 1) on $\left[\mathrm{S}_{4} \mathrm{O}_{6}{ }^{2-}\right]$, we postulate $\cdot\left(\mathrm{S}_{4} \mathrm{O}_{6}\right)_{2} \mathrm{ClO}_{2}{ }^{4-}$.

(iii) The roles of $\mathrm{S}_{2} \mathrm{O}_{3} \mathrm{ClO}_{2}{ }^{-}$and ${ }^{\circ} \mathrm{S}_{2} \mathrm{O}_{3}{ }^{-}$are well-established in the chlorine dioxide-thiosulfate reaction. ${ }^{6} \mathrm{We}$ thus include them here.

(iv) To obtain the 1:4 stoichiometric ratio, we suggest the intermediate ${ }^{\bullet} \mathrm{S}_{2} \mathrm{O}_{3}\left(\mathrm{ClO}_{2}\right)_{2}{ }^{-}$, whose second-order decomposition leads to eq 1 .

(v) For completeness, $\mathrm{S}_{4} \mathrm{O}_{6}\left(\mathrm{ClO}_{2}\right)_{2}{ }^{2-}$ was selected as a potential intermediate to account for a kinetic order slightly greater than one (Figure 2) with respect to chlorine dioxide.

This set of reactants, intermediates, and end products leads to 65 plausible mono- or bimolecular steps. Because the initial rate also depends on $\left[\mathrm{H}^{+}\right]$and $\left[\mathrm{Cl}^{-}\right]$, proton-, chloride-, and 
mixed proton- and chloride-catalyzed pathways of all 65 reactions were also considered initially. From the 260 initially included steps, the following model emerged from the systematic reduction procedure

$$
\begin{aligned}
& \mathrm{S}_{4} \mathrm{O}_{6}{ }^{2-}+\cdot \mathrm{ClO}_{2} \leftrightarrow \cdot \mathrm{S}_{4} \mathrm{O}_{6} \mathrm{ClO}_{2}^{2-} \\
& \mathrm{S}_{4} \mathrm{O}_{6}^{2-}+\cdot \mathrm{S}_{4} \mathrm{O}_{6} \mathrm{ClO}_{2}^{2-} \leftrightarrow \cdot\left(\mathrm{S}_{4} \mathrm{O}_{6}\right)_{2} \mathrm{ClO}_{2}^{4-} \\
& { }^{-} \mathrm{S}_{4} \mathrm{O}_{6} \mathrm{ClO}_{2}{ }^{2-} \rightarrow \mathrm{S}_{2} \mathrm{O}_{3} \mathrm{ClO}_{2}{ }^{-}+{ }^{\bullet} \mathrm{S}_{2} \mathrm{O}_{3}{ }^{-} \\
& v_{3}=k_{3}\left[\mathrm{H}^{+}\right]\left[\mathrm{S}_{4} \mathrm{O}_{6} \mathrm{ClO}_{2}^{2-}\right] \\
& \mathrm{S}_{2} \mathrm{O}_{3} \mathrm{ClO}_{2}{ }^{-}+{ }^{\bullet} \mathrm{S}_{4} \mathrm{O}_{6} \mathrm{ClO}_{2}{ }^{2-} \leftrightarrow \mathrm{S}_{4} \mathrm{O}_{6}{ }^{2-}+{ }^{\bullet} \mathrm{S}_{2} \mathrm{O}_{3}\left(\mathrm{ClO}_{2}\right)_{2}{ }^{-} \\
& { }^{-} \mathrm{S}_{2} \mathrm{O}_{3}{ }^{-}+{ }^{\bullet} \mathrm{ClO}_{2} \rightarrow \mathrm{S}_{2} \mathrm{O}_{3} \mathrm{ClO}_{2}{ }^{-} \\
& 2 \mathrm{~S}_{2} \mathrm{O}_{3} \mathrm{ClO}_{2}{ }^{-} \rightarrow \mathrm{S}_{4} \mathrm{O}_{6}\left(\mathrm{ClO}_{2}\right)_{2}{ }^{2-} \\
& v_{6}=k_{6}\left[\mathrm{H}^{+}\right]^{2}\left[\mathrm{~S}_{2} \mathrm{O}_{3} \mathrm{ClO}_{2}^{-}\right]^{2} \\
& \mathrm{~S}_{4} \mathrm{O}_{6}{ }^{2-}+\mathrm{S}_{4} \mathrm{O}_{6}\left(\mathrm{ClO}_{2}\right)_{2}{ }^{2-} \rightarrow 2^{\bullet} \mathrm{S}_{4} \mathrm{O}_{6} \mathrm{ClO}_{2}{ }^{2-} \\
& { }^{\bullet} \mathrm{ClO}_{2}+{ }^{\bullet}\left(\mathrm{S}_{4} \mathrm{O}_{6}\right)_{2} \mathrm{ClO}_{2}{ }^{4-} \rightarrow 2^{\bullet} \mathrm{S}_{4} \mathrm{O}_{6} \mathrm{ClO}_{2}{ }^{2-} \\
& \mathrm{S}_{4} \mathrm{O}_{6}{ }^{2-}+{ }^{\cdot} \mathrm{ClO}_{2} \rightarrow \mathrm{S}_{2} \mathrm{O}_{3} \mathrm{ClO}_{2}{ }^{-}+{ }^{\cdot} \mathrm{S}_{2} \mathrm{O}_{3}{ }^{-} \\
& v_{9}=k_{9}\left[\mathrm{H}^{+}\right]\left[\mathrm{Cl}^{-}\right]\left[\mathrm{S}_{4} \mathrm{O}_{6}{ }^{2-}\right]\left[{ }^{\bullet} \mathrm{ClO}_{2}\right] \\
& { }^{\bullet} \mathrm{ClO}_{2}+{ }^{\bullet} \mathrm{S}_{4} \mathrm{O}_{6} \mathrm{ClO}_{2}{ }^{2-} \rightarrow \mathrm{S}_{4} \mathrm{O}_{6}\left(\mathrm{ClO}_{2}\right)_{2}{ }^{2-} \\
& v_{10}=k_{10}\left[\mathrm{Cl}^{-}\right]\left[{ }^{\bullet} \mathrm{ClO}_{2}\right]\left[{ }^{\bullet} \mathrm{S}_{4} \mathrm{O}_{6} \mathrm{ClO}_{2}{ }^{2-}\right] \\
& \mathrm{S}_{4} \mathrm{O}_{6}\left(\mathrm{ClO}_{2}\right)_{2}{ }^{2-} \rightarrow{ }^{\bullet} \mathrm{ClO}_{2}+{ }^{\bullet} \mathrm{S}_{4} \mathrm{O}_{6} \mathrm{ClO}_{2}{ }^{2-} \\
& v_{11}=k_{11}\left[\mathrm{Cl}^{-}\right]\left[\mathrm{S}_{4} \mathrm{O}_{6}\left(\mathrm{ClO}_{2}\right)_{2}{ }^{2-}\right] \\
& 2^{\bullet} \mathrm{S}_{2} \mathrm{O}_{3}\left(\mathrm{ClO}_{2}\right)_{2}{ }^{-}+5 \mathrm{H}_{2} \mathrm{O} \rightarrow \\
& 4 \mathrm{SO}_{4}{ }^{2-}+3 \mathrm{Cl}^{-}+\mathrm{ClO}_{3}^{-}+10 \mathrm{H}^{+} \\
& v_{12}=k_{12}\left[\mathrm{H}^{+}\right]\left[\mathrm{Cl}^{-}\right]\left[\mathrm{S}_{2} \mathrm{O}_{3}\left(\mathrm{ClO}_{2}\right)_{2}{ }^{-}\right]^{2} \\
& { }^{\bullet} \mathrm{S}_{2} \mathrm{O}_{3}\left(\mathrm{ClO}_{2}\right)_{2}{ }^{-}+2 \mathrm{H}_{2} \mathrm{O} \rightarrow 2 \mathrm{SO}_{4}{ }^{2-}+\mathrm{Cl}^{-}+{ }^{\bullet} \mathrm{ClO}+4 \mathrm{H}^{+} \\
& v_{13}=k_{13}\left[\mathrm{H}^{+}\right]\left[\mathrm{S}_{2} \mathrm{O}_{3}\left(\mathrm{ClO}_{2}\right)_{2}^{-}\right] \\
& { }^{\bullet} \mathrm{ClO}+{ }^{\bullet} \mathrm{ClO}_{2}+\mathrm{H}_{2} \mathrm{O} \rightarrow \mathrm{HOCl}+\mathrm{ClO}_{3}{ }^{-}+\mathrm{H}^{+}
\end{aligned}
$$

Where no rate equation is indicated, the rate law is given either by the law of mass action (for equilibria) or by simple second-order kinetics.

\section{Discussion}

Step (R1) is the reversible formation of the intermediate $\cdot \mathrm{S}_{4} \mathrm{O}_{6} \mathrm{ClO}_{2}{ }^{2-}$. As emphasized above, this species is suggested by analogies to several other oxidation reactions of chlorine dioxide by thiosulfate, ${ }^{6}$ deprotonated hydrogen peroxide, ${ }^{14}$ and iodide. ${ }^{15}$ We were able to fit both rate constants in this equilibrium process. The value of the equilibrium constant indicates that a weak complex is formed, with a half-life of about $10 \mathrm{~s}$.

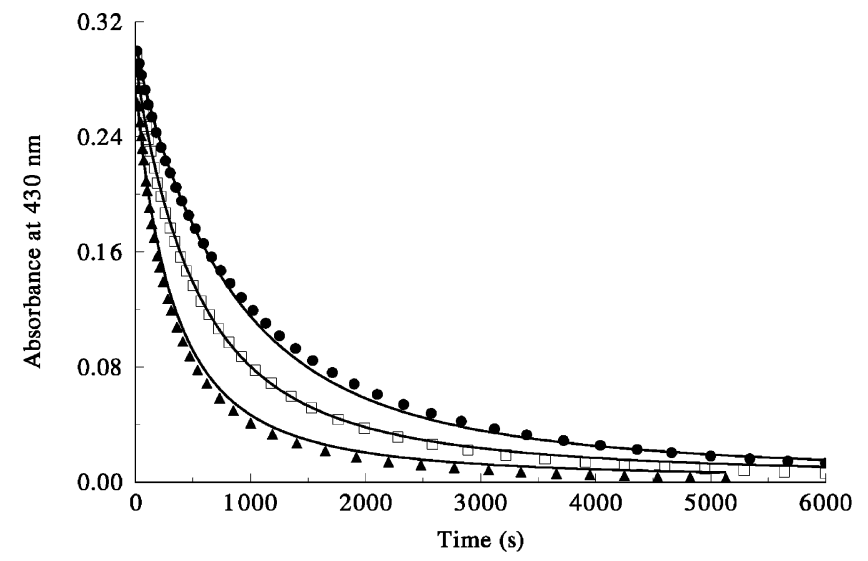

Figure 5. Measured (symbols) and calculated (solid lines) $430 \mathrm{~nm}$ absorbances at $\mathrm{pH}=5.25,\left[{ }^{\circ} \mathrm{ClO}_{2}\right]_{0}=0.002 \mathrm{M},\left[\mathrm{S}_{4} \mathrm{O}_{6}{ }^{2-}\right]_{0}=0.002 \mathrm{M}$, and $\left[\mathrm{Cl}^{-}\right]_{0}(\mathrm{M})=0(\bullet), 0.003(\square)$, and $0.01(\mathbf{\Delta})$.

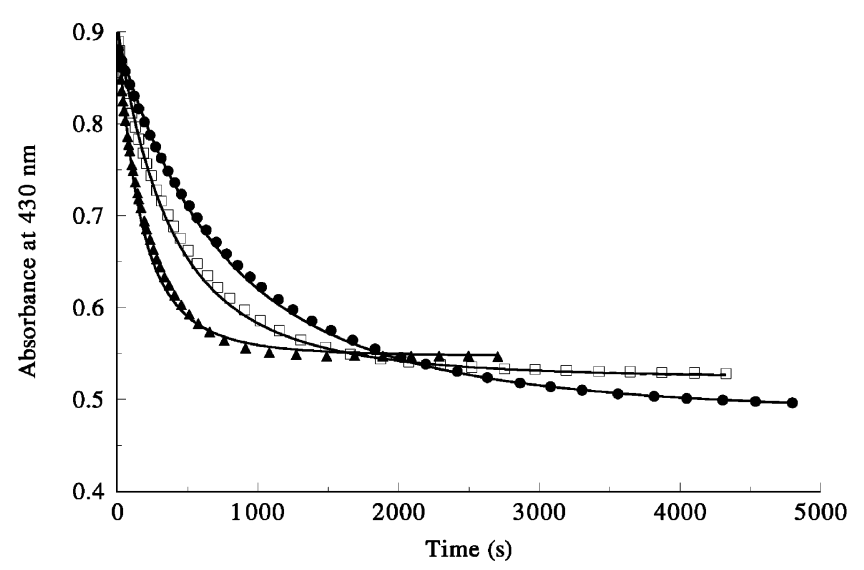

Figure 6. Measured (symbols) and calculated (solid lines) $430 \mathrm{~nm}$ absorbances at $\mathrm{pH}=4.55,\left[{ }^{\circ} \mathrm{ClO}_{2}\right]_{0}=0.006 \mathrm{M},\left[\mathrm{S}_{4} \mathrm{O}_{6}{ }^{2-}\right]_{0}=0.0006$ $\mathrm{M}$, and $\left[\mathrm{Cl}^{-}\right]_{0}(\mathrm{M})=0(\bullet), 0.003(\square)$, and $0.01(\mathbf{\Delta})$.

Step (R2) is the reversible formation of another radical, $\cdot\left(\mathrm{S}_{4} \mathrm{O}_{6}\right)_{2} \mathrm{ClO}_{2}{ }^{4-}$. The mixed-order dependence of the initial rate on $\left[\mathrm{S}_{4} \mathrm{O}_{6}{ }^{2-}\right]$ is best accounted for by including this intermediate. We find that the rate coefficient $k_{-2}$ is totally correlated with $k_{8}$, so that only their ratio can be determined independently by our fitting procedure. We set $k_{-2}=10 \mathrm{~s}^{-1}$. The forward rate coefficient $k_{2}$ is obtained from our data and the fitting procedure.

Step (R3) is the proton-catalyzed decomposition of the intermediate ${ }^{\circ} \mathrm{S}_{4} \mathrm{O}_{6} \mathrm{ClO}_{2}{ }^{2-}$ formed in (R1) to produce two intermediates. In the absence of chloride ion, this reaction initiates the conversion of the reactants to the end products. The rate coefficient $k_{3}$ is well-determined by our experiments.

Step (R4) describes the equilibrium between the intermediates $\mathrm{S}_{4} \mathrm{O}_{6}\left(\mathrm{ClO}_{2}\right)_{2}{ }^{2-}$ and $\mathrm{S}_{2} \mathrm{O}_{3} \mathrm{ClO}_{2}{ }^{-}$. Formally, it is simply a chlorine dioxide transfer between the two intermediates to yield species whose further reactions lead to the final products. Because $k_{4}$ is strongly correlated with $k_{6}$, we fixed $k_{4}=10^{4} \mathrm{M}^{-1} \mathrm{~s}^{-1}$, and only their ratio was calculated. The calculation procedure indicates that $10^{4} \mathrm{M}^{-1} \mathrm{~s}^{-1}$ is a lower bound on $k_{4}$.

Step (R5) is a fast radical-radical reaction. Our experiments provide only a lower bound: any value $k_{5} \geq 10^{7} \mathrm{M}^{-1} \mathrm{~s}^{-1}$ leads to the same simulated behavior. For our final calculations, we set $k_{5}=10^{8} \mathrm{M}^{-1} \mathrm{~s}^{-1}$, which is reasonable for a reaction of this type. Including the well-known reaction

$$
2^{\bullet} \mathrm{S}_{2} \mathrm{O}_{3}{ }^{-} \rightarrow \mathrm{S}_{4} \mathrm{O}_{6}{ }^{2-}
$$

with the known rate constant ${ }^{15}$ had no effect on the fit, so this reaction was omitted. 


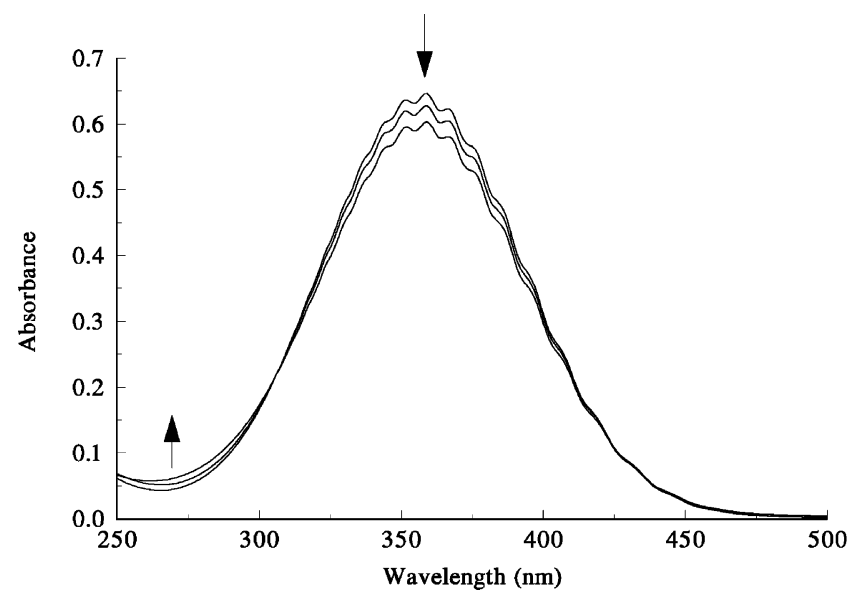

Figure 7. Spectra of chlorine dioxide solutions $\left(\left[{ }^{\circ} \mathrm{ClO}_{2}\right]=5.3 \times 10^{-4}\right.$ M) at $I=1.0 \mathrm{M}$ (adjusted with $\mathrm{NaClO}_{4}$ ) and at three chloride concentrations $(0,0.1,1 \mathrm{M})$. Arrows show direction of increasing chloride concentration.

Step (R6) is the proton-catalyzed recombination of $\mathrm{S}_{2} \mathrm{O}_{3} \mathrm{ClO}_{2}{ }^{-}$. The rate equation strongly suggests that $\mathrm{S}_{2} \mathrm{O}_{3} \mathrm{ClO}_{2}{ }^{-}$is capable of protonation under the conditions used in our experiments. Because we do not have any independent information about the acid dissociation constant of this species, we do not include $\mathrm{HS}_{2} \mathrm{O}_{3} \mathrm{ClO}_{2}$ in our proposed model. As noted above, only the ratio $k_{4} / k_{6}$ rather than the actual rate coefficient $k_{6}$ can be determined from our experiments.

Step (R7) is the back formation of $\cdot \mathrm{S}_{4} \mathrm{O}_{6} \mathrm{ClO}_{2}{ }^{2-}$ from $\mathrm{S}_{4} \mathrm{O}_{6}\left(\mathrm{ClO}_{2}\right)_{2}{ }^{2-}$ and tetrathionate ion. The rate coefficient $k_{7}$ cannot be determined from our experiments, because it correlates with $k_{11}$. It was fixed at its lower bound, $10^{5} \mathrm{M}^{-1} \mathrm{~s}^{-1}$.

Step (R8) is the back formation of $\cdot \mathrm{S}_{4} \mathrm{O}_{6} \mathrm{ClO}_{2}{ }^{2-}$ from $\cdot\left(\mathrm{S}_{4} \mathrm{O}_{6}\right)_{2} \mathrm{ClO}_{2}{ }^{4-}$ and chlorine dioxide. The rate coefficient $k_{8}$ is well-determined by our experiments.

Step (R9) is the most critical part of the proposed model. We tried to replace this reaction with the more plausible

$$
\begin{gathered}
\cdot \mathrm{S}_{4} \mathrm{O}_{6} \mathrm{ClO}_{2}{ }^{2-} \rightarrow \mathrm{S}_{2} \mathrm{O}_{3} \mathrm{ClO}_{2}{ }^{-}+{ }^{\bullet} \mathrm{S}_{2} \mathrm{O}_{3}{ }^{-} \\
r_{4}=k_{4}\left[\mathrm{H}^{+}\right]\left[\mathrm{Cl}^{-}\right]\left[\mathrm{S}_{4} \mathrm{O}_{6} \mathrm{ClO}_{2}{ }^{2-}\right]
\end{gathered}
$$

with no success. This result suggests that (R9) takes place exclusively via another intermediate formed from the reaction between protonated tetrathionate and ${ }^{\circ} \mathrm{Cl}_{2} \mathrm{O}_{2}{ }^{-}$. Because there is no information in the literature about the formation of a weak complex between chlorine dioxide and chloride ion, we sought evidence for its existence. Figure 7 shows spectra of chlorine dioxide solutions at constant $(1.0 \mathrm{M})$ ionic strength at several chloride concentrations. The structure of the spectra and the presence of an isosbestic point at $306 \mathrm{~nm}$ strongly suggest the presence of ${ }^{\bullet} \mathrm{Cl}_{2} \mathrm{O}_{2}{ }^{-}$.

Step (R10) is the chloride-catalyzed formation of $\mathrm{S}_{4} \mathrm{O}_{6}$ $\left(\mathrm{ClO}_{2}\right)_{2}{ }^{2-}$. The rate coefficient $k_{10}$ was calculated from our experiments.

Step (R11) is the chloride-catalyzed back reaction of step (R10). As mentioned above, $k_{11}$ correlates with $k_{7}$, so only their ratio could be determined from our experiments. The existence of ${ }^{\cdot} \mathrm{Cl}_{2} \mathrm{O}_{2}{ }^{-}$suggested above implies that reactions (R10) and (R11) can be replaced by the following equilibrium:

$$
{ }^{\bullet} \mathrm{Cl}_{2} \mathrm{O}_{2}{ }^{-}+{ }^{-} \mathrm{S}_{4} \mathrm{O}_{6} \mathrm{ClO}_{2}{ }^{2-} \rightarrow \mathrm{S}_{4} \mathrm{O}_{6}\left(\mathrm{ClO}_{2}\right)_{2}{ }^{2-}+\mathrm{Cl}^{-}
$$

Step (R12) leads to the 1:4 stoichiometry of eq 1. The dependence of the rate on the chloride concentration is consistent
TABLE 3: Rate Constants Used in the Fitting Procedure ${ }^{a}$

\begin{tabular}{llc}
\hline \multicolumn{1}{c}{ rate constant } & \multicolumn{1}{c}{ value } & average deviation \\
\hline$k_{1}\left(\mathrm{M}^{-1} \mathrm{~s}^{-1}\right)$ & $1.02 \pm 0.01$ & 0.156 \\
$k_{-1} \times 10^{2}\left(\mathrm{~s}^{-1}\right)$ & $4.15 \pm 0.10$ & 0.0127 \\
$k_{2} \times 10^{-1}\left(\mathrm{M}^{-1} \mathrm{~s}^{-1}\right)$ & $1.93 \pm 0.03$ & 0.0196 \\
$k_{-2}\left(\mathrm{~s}^{-1}\right)$ & 10 & 0.0071 \\
$k_{3} \times 10^{-2}\left(\mathrm{M}^{-1} \mathrm{~s}^{-1}\right)$ & $8.83 \pm 0.19$ & 0.0844 \\
$k_{4} \times 10^{-4}\left(\mathrm{M}^{-1} \mathrm{~s}^{-1}\right)$ & 1 & 0.0582 \\
$k_{-4} \times 10^{-1}\left(\mathrm{M}^{-1} \mathrm{~s}^{-1}\right)$ & $5.91 \pm 0.17$ & 0.0056 \\
$k_{5} \times 10^{-8}\left(\mathrm{M}^{-1} \mathrm{~s}^{-1}\right)$ & 1 & 0.0274 \\
$k_{6} \times 10^{-14}\left(\mathrm{M}^{-3} \mathrm{~s}^{-1}\right)$ & $2.51 \pm 0.13$ & 0.0090 \\
$k_{7} \times 10^{-5}\left(\mathrm{M}^{-1} \mathrm{~s}^{-1}\right)$ & 1 & 0.0088 \\
$k_{8} \times 10^{-4}\left(\mathrm{M}^{-1} \mathrm{~s}^{-1}\right)$ & $1.23 \pm 0.03$ & 0.0162 \\
$k_{9} \times 10^{-6}\left(\mathrm{M}^{-3} \mathrm{~s}^{-1}\right)$ & $4.06 \pm 0.03$ & 0.0088 \\
$k_{10} \times 10^{-2}\left(\mathrm{M}^{-2} \mathrm{~s}^{-1}\right)$ & $8.95 \pm 0.18$ & 0.0050 \\
$k_{11} \times 10^{-2}\left(\mathrm{M}^{-1} \mathrm{~s}^{-1}\right)$ & $9.24 \pm 0.48$ & 0.0046 \\
$k_{12} \times 10^{-11}\left(\mathrm{M}^{-3} \mathrm{~s}^{-1}\right)$ & $6.84 \pm 0.19$ & 0.0185 \\
$k_{13} \times 10^{-3}\left(\mathrm{M}^{-1} \mathrm{~s}^{-1}\right)$ & 1 & 0.0087 \\
$k_{14} \times 10^{-8}\left(\mathrm{M}^{-1} \mathrm{~s}^{-1}\right)$ & 1 & 0.0086
\end{tabular}

${ }^{a}$ The third column shows the average deviation if the given step is omitted from the model.

with the experimental observation that a perfect 1:4 stoichiometry is only obtained when appreciable chloride is present initially. The rate coefficient $k_{12}$ is correlated with both $k_{-4}$ and $k_{13}$.

Steps (R13) and (R14) are responsible for the deviation from the 1:4 stoichiometry. Our data give a lower bound of $k_{13} \geq$ $10^{3} \mathrm{M}^{-1} \mathrm{~s}^{-1}$. Because $k_{13}$ correlates with $k_{12}$ and $k_{-4}$, we fixed $k_{13}$ at this value and were able to calculate the ratios $k_{-4} / k_{13}$ and $k_{12} / k_{13}$. No value for $k_{14}$ could be determined from our experiments. It is essential only that (R14) be faster than (R13) so that ${ }^{\bullet} \mathrm{ClO}$ does not accumulate. It is reasonable to assume that the radical-radical reaction (R14) is close to the diffusioncontrolled limit, so we set $k_{14}=10^{8} \mathrm{M}^{-1} \mathrm{~s}^{-1}$. We also attempted to replace (R13) by

$$
\begin{aligned}
{ }^{-} \mathrm{S}_{2} \mathrm{O}_{3}\left(\mathrm{ClO}_{2}\right)_{2}{ }^{-}+{ }^{\bullet} \mathrm{ClO}_{2}+2 \mathrm{H}_{2} \mathrm{O} \rightarrow \\
2 \mathrm{SO}_{4}{ }^{2-}+\mathrm{HOCl}+2{ }^{\bullet} \mathrm{ClO}+3 \mathrm{H}^{+}
\end{aligned}
$$

Formation of ${ }^{-} \mathrm{S}_{2} \mathrm{O}_{3}\left(\mathrm{ClO}_{2}\right)_{2}{ }^{-}$along with eq 6 and step (R14) would have led to a simpler stoichiometric equation than eq 2

$$
\begin{aligned}
\mathrm{S}_{4} \mathrm{O}_{6}{ }^{2-}+10^{\circ} \mathrm{ClO}_{2}+8 \mathrm{H}_{2} \mathrm{O} \rightarrow \\
4 \mathrm{SO}_{4}{ }^{2-}+4 \mathrm{ClO}_{3}{ }^{-}+6 \mathrm{HOCl}+10 \mathrm{H}^{+}
\end{aligned}
$$

but we could not obtain a satisfactory fit. Because formation of - $\mathrm{S}_{2} \mathrm{O}_{3}\left(\mathrm{ClO}_{2}\right)_{2}{ }^{-}$followed by steps (R13) and (R14) yields eq 2, this last reaction was chosen to account for the deviation from the $1: 4$ ratio.

Table 3 summarizes the rate constants obtained in the fitting procedure. Where no standard deviation is given for a rate constant, that parameter was fixed during the fitting. Using all of the steps in the proposed model, the average deviation was found to be $0.0042 \mathrm{au}$, which is close to the experimentally achievable limit of error of the absorbance measurement. The third column of the table shows the average deviation if the given step is omitted from the model. We see that omitting any step from the model would increase the average deviation by at least $10 \%$, implying that all proposed steps are necessary for describing the behavior of the system.

As an additional test of the efficacy of our method, we performed the following test of its ability to predict the results of independent experiments not used in the fitting. Runs 3, 12$14,17,20,25,34-36,39,42,47,56-58,61,64,69,78-80$, 83 , and 86 were removed from the data set, and the rate 
constants were determined using the remaining 64 runs. The kinetics parameters obtained differed from those found with the full set of 88 runs by $1-4 \%$, and the average deviation increased only to $0.0043 \mathrm{au}$. We then used these parameters to fit (predict) the data from the remaining 24 runs. The average deviation was $0.0044 \mathrm{au}$.

\section{Conclusion}

This work is the first effort to unravel the kinetics and mechanism of the chlorine dioxide-tetrathionate reaction. The proposed model may require further refinement, but it is already able to describe, over a wide range of reactant concentrations, the most important characteristics of the kinetics curves within the experimentally achievable limit of error. The $\mathrm{pH}-$ and chloride ion-dependences of the kinetics unambiguously show that the reaction is autocatalytic with respect to both $\mathrm{H}^{+}$and $\mathrm{Cl}^{-}$. The proton autocatalysis is completely suppressed by the acetate-acetic acid buffer. Although the chloride autocatalysis does not result in sigmoidal kinetic curves in the concentration range used in our experiments, there should exist a range of reactant concentrations where this behavior is observable.

It has been reported that the chloride ion not only catalyzes the decomposition of chlorous acid but also alters its stoichiometry. ${ }^{16}$ The results presented here demonstrate a similar effect of the chloride ion in the chlorine dioxide-tetrathionate reaction. The effect of chloride ion on the chlorine dioxide-hypochlorous acid reaction is also well-established. ${ }^{17}$ More recently, the role of $\mathrm{Cl}^{-}$has been discussed in the aqueous chlorine-chlorite reaction. ${ }^{18}$ These examples appear to establish a general mode of catalysis of the reactions of the oxychlorine species by the otherwise sluggish chloride ion. Further experiments to clarify this effect are in progress in our laboratory, and we hope that the results presented here will inspire theoretical investigations into the stabilities of some of the proposed intermediates.
Acknowledgment. This work was supported by the National Science Foundation (Grant No. CHE-0306262) and the Hungarian Research Fund (Grant No. T030446). A.K.H. is grateful for the financial support of an OTKA postdoctoral fellowship (Grant No. D38001). We thank Kenneth Kustin for helpful comments.

Supporting Information Available: Files containing the measured and calculated absorbances for all 88 kinetics curves at the three experimental wavelengths are available. This material is available free of charge via the Internet at http://pubs.acs.org.

\section{References and Notes}

(1) Orbán, M.; Epstein, I. R. J. Phys. Chem. 1982, 86, 3907. 431.

(2) Orbán, M.; De Kepper, P.; Epstein, I. R.J. Phys. Chem. 1982, 86,

(3) Nagypál, I.; Bazsa, Gy.; Epstein, I. R. J. Am. Chem. Soc. 1986, 108,3635 .

(4) Nagypál, I.; Epstein, I. R. J. Phys. Chem. 1986, 90, 6285. 2954.

(5) Peintler, G.; Nagypál, I.; Epstein, I. R. J. Phys. Chem. 1990, 94

(6) Horváth, A. K.; Nagypál, I. J. Phys. Chem. A 1998, 102, 7267

(7) Horváth, A. K.; Nagypál, I. Int. J. Chem. Kinet. 2000, 32, 395.

(8) Csordás, V.; Bubnis, B.; Fábián, I.; Gordon, G. Inorg. Chem. 2001, $40,1833$.

(9) Horváth, A. K.; Nagypál, I.; Epstein, I. R. J. Am. Chem. Soc. 2002, 124, 10956 .

(10) Peintler, G.; Nagypál, I.; Jancsó, A.; Kustin, K.; Epstein, I. R. J. Phys. Chem. A 1997, 101, 8013.

(11) Peintler, G. ZiTa, Version 5.0, a Comprehensive Program Package for Fitting Parameters of Chemical Reaction Mechanism; Attila József University: Szeged, Hungary, 1989-1998.

(12) Hoffmann, E. A.; Nagypál, I.; Epstein, I. R.; Kustin, K. In preparation.

(13) Ni, Y.; Wang, X. Can. J. Chem. Eng. 1996, 75, 31.

(14) Fábián, I.; Gordon, G. Inorg. Chem. 1997, 36, 2494.

(15) Dogliotti, L.; Hayon, E. J. Phys. Chem. 1968, 72, 1800.

(16) Horváth, A. K.; Nagypál, I.; Peintler, G.; Epstein, I. R.; Kustin, K. J. Phys. Chem. A 2003, 107, 6966.

(17) Yin, G. H.; Ni, Y. H. Can. J. Chem. Eng. 1998, 76, 921

(18) Nicoson, J. S.; Margerum, D. W. Inorg. Chem. 2002, 41, 342. 